\title{
Analysis and Discussion on Chinese College Students' Moral Characteristics and Its Countermeasures
}

\author{
Yanling Zhang \\ Northeast Petroleum University at Qinhuangdao, Qinhuangdao, China \\ Email: w ddan@163.com \\ Received 26 January 2015; accepted 3 March 2015; published 6 March 2015 \\ Copyright (C) 2015 by author and Scientific Research Publishing Inc. \\ This work is licensed under the Creative Commons Attribution International License (CC BY). \\ http://creativecommons.org/licenses/by/4.0/ \\ c) (i) Open Access
}

\begin{abstract}
The moral education of Chinese colleges and universities should start with the moral characteristics of contemporary college students so as to find solutions and countermeasures. The paper suggests the concordant development of school education, social education and family education, forming an organic whole, to improve the current moral education jointly, which is a good way to improve the moral level of the contemporary college students.
\end{abstract}

\section{Keywords}

Moral Characteristics, School Education, Social Education, Educational Method, Educational Objectives

\section{Introduction}

Contemporary Chinese college students grew up in an era of dramatic social change. Social changes to people’s spiritual world also brought great shock to the inherent pattern and the traditional idea; people's moral values presented unprecedented diversification and complexity of the situation. Because of the characteristics of college students, these changes are prominent in college students. Improving college students' ideological and moral qualities is an important content of the construction of spiritual civilization in the whole society, and is also an important task of college education work.

Moral education guides the behavior of people by normative guidance, evaluation of public opinion and example inspiration to cultivate people's moral quality [1]. Moral construction contents mainly include four aspects: 1) the thought of serving the people, 2) the collectivism thought, 3) the "five love", namely, loving the motherland, loving the people, loving labor, loving science and loving socialism, 4) the social morality, the pro- 
fessional ethics and the family virtues. Considering the characteristics of college students, the following contents should be paid special attention during the moral education: patriotism and collectivism thought education, ideological education, ideal education to serve the people, social morality education, learning knowledge, loving science, etiquette education, etc. College students should be good examples in observing social morality and purifying the social atmosphere, be particular about credit and honest, respect the elderly and love the children, be civilized, take good care of public property, etc. The Chinese nation is a nation advocating etiquette. "Behaving in a refined and civil manner", "self-disciplined gentleman" are the goals of ancient Chinese literary intelligentsia. In the present society, there are a few people impolite. And there are also some college students impolite, who don't understand the "rules". They should take etiquette education to make their manners be in line with their identity, and thus to become knowledgeable and cultured with beautiful language and behavior. In conclusion, correct world outlook should be established for college students by education, as well as good moral ideas and ideal faith, to achieve "patriotism and observance of law, courtesy and honesty, unity and friendship, diligence and self-improvement, and professional dedication".

\section{Moral Characteristics of Contemporary College Students}

\subsection{Diversified and Unstable Moral Value of College Students}

Due to the difference among individual students, such as family environment, life style and life experiences, and the diversification of information in the present era, college students' thought and moral value are extremely diversified. For example, in general students of higher grades are more mature and sophisticated than students of lower grades. Students from Beijing, Tianjin, Shanghai and southeast coastal areas think more highly of material benefit and utility than students from the central and western regions. Most of the students' values tend to the pursuit of both material benefit and utility. In general, successful career and happy family are their goals. Meanwhile, some of students feel helpless facing society and lose the development direction of self morality in the materialistic society. Only very few students are inextricably bogged down in the quagmire of extreme individualism and money worship, and finally abandoned by society.

College students are in the growth stage, so their opinions on many issues are not defined. Their world outlook, outlook on life and the values are in the formation period. Therefore, the choice and judgment of their moral concepts are easily influenced by the external environment, in an unstable state. A student may change his/her judgment and draw an opposite conclusion on the same issue after listening to a hero's report or when encountering a bad thing. Due to the difference of interest distribution to social groups and the diversification of values under market economy, college students have increasingly lots of confusion and contradiction on values. On the one hand they feel everyone is responsible for his country. On the other hand, they have a lot of doubts when they see the money worship and ultra-individualism. From one aspect, they have received many positive views in school. From another aspect, they may feel not know what course to take when they see some negative corruptions.

\subsection{College Students' Main Body Consciousness and Competition Consciousness in Moral Development}

The openness of the commodity economy enables students to enhance independence, self reliance and active participation in awareness. They trust their own strength and focus on the development of self. They make full use of the network and a variety of other media to obtain information timely, know about domestic and international events and enrich knowledge, forming their own view on things. The main body consciousness, from the point view of society, is a great progress and is the embodiment of college students to mature and independent consciousness.

Market economy requires the exchange of equal value and the survival of the fittest. Along with China's transition from planned economy system to market economy system, the competition mechanism is introduced to human life in all aspects, which objectively arouses people's participation consciousness and competition consciousness [2]. For students living in the "small society" of school, participation consciousness and competition consciousness have been internalized as part of their life. Some students advocate self in life values. With the individual as main body, they emphasize the importance of personal struggle and the realization of self value. Some students pay too much attention to the personal struggle and personal development, resulting that they lack collective and collaborative concept, service and dedication spirit. In social activities they want to be leader rather than a supporting role. They are not willing to do repetitive and output work, and always worried being 
delayed, their talent being buried or being wasted.

\subsection{The General Tendency of College Students to Pragmatism and Utilitarianism}

College students' ideas have a tendency to pragmatism and utilitarianism. Many students think today's society is a highly competitive society, so they shall learn to express themselves in order to survive in the society and shall continue to realize their own value in the process of competition. In their ideas, personal freedom and self value are the most important. They put their own interest first and then others, and try the best to maximize their own interest and do not harm others' interest. If a conflict occurs between collective interests and personal interests, they first maintain their personal interest. This pragmatism and utilitarianism are prevalent among students. As long as it is beneficial for individuals, they often achieve their goal at all costs.

\subsection{College Students' Passivity in the Acceptance of Moral Education}

The students lack self consciousness in the acceptance of moral education and are very passive. Many students muddle through in their examination in order to obtain credits or passively accept the moral education due to other reasons. They lack the enthusiasm and initiative in the pursuit and acceptance of moral education. The paper analyzes, first, according to Maslow's theory of needs, human needs are hierarchical. The needs of survival come first, and have the characteristics of ease and initiative. The spiritual needs, especially the highest level, are non survival needs unique to human nature. The spiritual needs need to be cultivated and brought up by acquired environment, and cannot being produced spontaneously. Second, the moral education could work over a long process, including infiltration, accumulation and transformation. Students are not easy to deeply realize the importance of moral education. Compared with society, campus environment is relatively simple. The conflicts the students meet are relatively single, with no significant political and economic contradictions. Even there are some bad behaviors, the influence on their study and life is not great. Therefore, they cannot realize the important effect of the moral education in their life.

\section{The Reinforcement of College Students' Moral Construction through the Three Aspects of School, Family and Society}

\subsection{Guidance Is the Key of School Education}

It is suggested to focus on the construction of "Ideological and Political Theory Course" and give full play to its effects of main channel and main battle position in the moral education [3]. The paper advises to cultivate teachers' ideological and political theory through various channels, to further improve their ideological and political quality and the professional quality. Meanwhile, the moral education runs through the teaching of relevant subjects, such as economics and laws. In addition, we can carry out staff education. All staff of all departments should make themselves an example, setting a good example for the students. We can make full use of campus network, with advantages of its large capacity, wide coverage and rich information resources, and use healthy content to attract students, and thus the students may be educated [4]. We may stress the construction of campus culture and meet the needs of students comprehensively through rich and colorful activities, involving in science and technology, culture, entertainment, arts and etc., to make up for the deficiencies of classroom teaching. We may integrate the moral education into the construction of campus culture to create a good atmosphere at campus, playing a role of silent education and invisible education in the forming and developing of students' moral character. Students' main body consciousness is being built up gradually, so we can use a variety of ways to carry out moral education activities by fully using their main body role to let students understand and accept basic moral beliefs. Due to the diversity of moral values, we should start from reality in moral education and carry out different education according to different types and different levels of individual. We could cultivate and make good citizens with patriotism, senior professional personnel with dedicated spirit and innovation, and advanced people with lofty ideal out of college students. Meanwhile, every student has the original power to struggle from different starting point and strives to higher level.

\subsection{The Role of Family in Moral Education Is Unique}

Swiss educator Fistalozi once pointed out, the main place of moral education is the family [5]. Parents are their children's first teachers. The formation of human morality is not a short duration of time, but starts from child- 
hood, which is greatly influenced by the family. Therefore, the influence of family education on children is profound and long-term. In moral education, family should play an important role. The family, especially the parents, should set an example ethically, meanwhile should always concern about their children's growth. They should get in touch with the school as much as possible to know their children's life and study in college, especially the ideological aspect of quality. Afterwards, they could guide and educate their children specifically depending on the circumstances. As a result, the family education would make students better in study and qualified in moral quality and promote college students' self education and self perfection, playing a positive role in college students' moral socialization.

But now there exist problems in the moral education and moral role model of parents who pay attention to the private morality education and ignore the social morality education. For example, the school educates students solidarity and friendship, and to care about others, while parents unconsciously tell children not to suffer losses outside. They advocate individualism, money worship and hedonism. Some parents orally educate their children to learn seriously, but they do not create a good family atmosphere for children. Their words belie their acts. Some parents teach their children to be moral, but they themselves do some immoral things, setting a bad example for their children and affecting the establishment of students' correct outlook on life and moral values

\subsection{The Social Influence Is Significant}

People are living in this big social environment. The social atmosphere influences and edifies people's values just like "rain moistening everything silently", which may form a strong power to urge people acting in accordance with the social prevalent behavior pattern and may create an atmosphere of public opinion in a certain range, tangibly and intangibly exerting pressure on people who do not want to act this way [6]. Therefore, the whole society should form a good social custom which promotes righteousness and resist unhealthy trend, and we should attach importance to the civilizing influence of social morality on college students. In this way, a good environment will be formed for moral education, which must be able to promote the development of college students' moral education constantly.

The media play an increasingly important role in the contemporary society, and you can found it everywhere. Therefore, first of all we should pay attention to the influence of media culture. The media should do more to publicize the positive touching stories, forming a moral-stressing public opinion in society. Secondly, we should pay attention to the moral rationality in the regulation system and the social management [7]. The ethical pursuit and value orientation should be reflected clearly in the system, so that people are willing to make the correct choice of value. For example, in the period of social transformation, the social security system was not perfect and social support on morality was insufficient, which result in the rise of moral costs and produce a lot of adverse effects. On the issue of behaving righteously, our country lacks system safeguard matching with the mainstream value advocating in the society. Therefore, a lot of people behaving righteously have not been treated fairly. The data shows that $45 \%$ of people behaving righteously have sequela on their action, resulting in the difficulties of living, medical, housing, education and employment. If things go on like this, people may be indifferent or not willing to help other for a just case. Therefore, it is an important step to strengthen the system and law support on morality, perfect the moral rationality in the social security system as soon as possible in order to improve citizens' moral quality, reduce the moral cost and promote the social moral progress.

\section{Conclusions}

College students are the hope of the country with great trust of the people and historical responsibility. The university period is an important stage for the formation, development and maturity of moral consciousness, which has important impacts on one's life. So college students should not only learn scientific and cultural knowledge and have a healthy body, but also strengthen ideological and moral culture to become an all-round person of good morality, intelligence and physique.

With the development of the times, the progress of the society, and the change of people's concept, college students' ideological and moral status has also been changed. Adapting to the change of the education object and exploring new solutions should be the directions of the ideological and political workers.

To sum up, the author suggests the concordant development of social education, school education and family education, forming an organic whole. We can use all social forces to improve the current moral education and raise the level of moral education of the contemporary college students. 


\section{References}

[1] Xin, D.J. (2012) Analysis on Characteristics of Moral Development of College Students under the Background of the Construction of Harmonious Society. Chinese After-School Education, 25, 9-10.

[2] Huang, H. (2014) Discussion and Analysis on the Education of Moral Values of College Students. 5.

[3] Jiang, G.H. and Gao, L.H. (2013) Analysis on the Deviation and Causes of College Students' Morality. Leadership Science Forum, 5, 28-29.

[4] Li, M. (2014) Impact of Internet on College Students' Moral socialization and the Countermeasures. Party Building and Ideological Education in School, 2, 70-71.

[5] Lou, X.G. (2009) College Students’ Ideological and Moral Status Quo and Characteristics of the Analysis. China's Adult Education, 9, 116-117.

[6] Qin, Y.H. and Song, Q.L. (2005) Moral Personality of Contemporary College Students with the Construction of Our Country. Heilongjiang Province Higher Education Research, 7, 108-110.

[7] Su, Y.Q. and Xiao, Y.Z. (2003) Contemporary Chinese College Students’ Moral Personality and Build. Journal of Chengdu University of Technology, 4, 42-44. 